\title{
GAMBARAN KESEJAHTERAAN SUBJEKTIF PADA PEREMPUAN DEWASA YANG MERAWAT ORANG TUA DENGAN DEMENSIA
}

\author{
Arina Shabrina, Eka Riyanti Purboningsih, \& Tiara Ratih Widiastuti \\ Departemen Psikologi Sosial, Fakultas Psikologi, Universitas Padjajaran, Jl. Raya Bandung Sumedang KM.21, Hegarmanah, Kec.Jatinangor,
} Sumedang, Jawa Barat 45363, Indonesia

Korespondensi: arinashabrina@outlook.com

\section{SUBJECTIVE WELL-BEING OF ADULT DAUGHTER CAREGIVERS OF A PARENT WITH DEMENTIA}

\begin{abstract}
Dementia is a neurodegenerative disorder associated with memory, language, problem solving, and other cognitive abilities. The psychological impact of dementia is not only experienced by the patients, but also by family caregivers, which could be associated with their subjective well-being. In Indonesia, children were culturally expected to take care their elderly parents and it is more emphasized on daughters. The purpose of this study was to explore the subjective well-being of adult daughter caregivers of a parent with dementia. A case study utilizing semi-structured interviews was conducted to four adult daughters (aged between 30-60 years) who performed as a caregiver. Two themes emerged from the cognitive component of subjective well-being:living arrangement and social relation with patients. Caregivers often experience negative emotions related to their role as a caregiver. The findings indicate that the dynamics of caregiver's well-being was highly associated with their attitudes in accepting the role of taking care for their demented parents.
\end{abstract}

Manuscript type: Original Research

\section{Article history:}

Received 13 July 2020

Received in revised form 14 July 2020

Accepted 29 September 2020

Available online 4 December 2020

\section{Keywords:}

caregiver

dementia

subjective well-being

\begin{abstract}
Abstrak
Demensia adalah penyakit neurodegeneratif yang berhubungan dengan memori, bahasa, pemecahan masalah, dan kemampuan kognitif lainnya. Tidak hanya pada pasien demensia, anggota keluarga yang menjadi pendamping juga dapat mengalami beban psikologis yang terkait dengan kesejahteraan subjektifnya. Di Indonesia, anak secara budaya diharapkan untuk merawat orang tuanya yang lansia dan ekspektasi tersebut lebih ditekankan pada anak perempuan. Tujuan penelitian ini adalah untuk menggambarkan kesejahteraan subjektif perempuan dewasa yang merawat orang tua dengan demensia. Studi kualitatif ini merupakan studi kasus yang menggunakan wawancara semi terstruktur kepada empat anak perempuan dewasa (berusia antara 30-60 tahun) yang merawat orang tua lansia penderita demensia. Dua tema muncul dari komponen kognitif kesejahteraan subjektif: pengaturan hidup bersama dan hubungan sosial dengan pasien. Pendamping seringkali mengalami emosi negatif yang berkaitan dengan peran mereka sebagai pendamping. Temuan penelitian ini menunjukkan bahwa dinamika kesejahteraan subjek berhubungan dengan sikap penerimaan terhadap peran pendamping orang tua dengan demensia.
\end{abstract}

Kata Kunci: demensia, kesejahteraan subjektif, pendamping

\section{Dampak dan Implikasi dalam Konteks Ulayat}

Penelitian ini menunjukkan adanya kekhasan relasi antara orang tua dan anak dalam konteks merawat orang tua dengan demensia di Indonesia yang dipengaruhi, khususnya oleh budaya patriarkal. Melihat dari sudut pandang sosial masyarakat Indonesia, terdapat ekspektasi budaya bagi anak-anak untuk memenuhi kewajibannya pada orang tua dengan merawat dan mengurus orang tuanya yang sudah lansia. Secara khusus, peran gender tradisional terilustrasikan melalui studi ini di mana peran merawat dan mengurus orang tua lebih ditekankan pada anak perempuan dan dipandang sebagai hal yang sudah sepatutnya dilakukan. Temuan penelitian ini memperlihatkan pengalaman anak perempuan dewasa yang mengemban tanggung jawab sebagai pendamping pasien demensia, di mana mereka menghadapi kesulitan untuk menerima kondisi kehidupannya dan juga merasakan perasaan-perasaan negatif selama menjalani peran sebagai pendamping. 


\section{PENDAHULUAN}

Penduduk lansia di Indonesia mengalami peningkatan seiring meningkatnya angka harapan hidup dan menurunnya angka kematian. Pada tahun 2019, jumlah penduduk lansia di Indonesia mencapai 25,64 juta jiwa (sebesar 9.60\% dibandingkan dengan jumlah seluruh penduduk) yang menunjukkan Indonesia sedang bertransisi menuju negara dengan struktur penduduk tua (Badan Pusat Statistik, 2019). Salah satu gangguan kesehatan dan penyebab disabilitas yang umum dialami oleh populasi lansia secara global adalah demensia (World Health Organization, 2006). Berdasarkan data dari World Alzheimer Report tahun 2018, prevalensi penduduk lansia yang menderita penyakit demensia secara global akan diprediksi terus meningkat setiap tahunnya (Patterson, 2018). Jumlah total penderita demensia di seluruh dunia diproyeksikan mencapai 82 juta pasien pada tahun 2030 dan 152 juta pasien pada tahun 2050 (World Health Organization, 2019). Sebagian besar dari peningkatan ini disebabkan oleh meningkatnya angka harapan hidup dan bertambahnya jumlah penderita demensia yang tinggal di negara berkembang.

Demensia adalah sekumpulan gejala yang dicirikan dengan penurunan fungsi memori, bahasa, penyelesaian masalah dan kemampuan kognitif lainnya (Wilson dkk., 2012). Pasien akan mengalami perubahan perilaku dan kondisi fisik secara terus-menerus sampai mereka harus berada di tempat tidur dan bergantung penuh pada pendamping untuk melakukan aktivitas sehari-hari (Bailes dkk., 2016). Kondisi kesehatan neurologis yang kronis ini memiliki durasi dan onset penyakit yang panjang serta sulit diprediksi, sehingga pasien membutuhkan anggota keluarga atau orang lain untuk merawat (Sullivan \& Miller, 2015). Anggota keluarga yang menjadi pendamping berperan sebagai individu yang memberikan dukungan fisik, emosional, finansial, dan seringkali tanpa pelatihan dan tidak mendapatkan kompensasi dalam merawat pasien (Goldberg \& Rickler, 2011).

Proses merawat pasien dapat membuat pendamping kewalahan akibat kompleksitas dari perawatan, beban emosional yang dialami, serta perasaan bertanggung jawab untuk mengurangi penderitaan pasien (Vizzachi dkk., 2015). Pendamping pasien demensia yang dirawat di rumah memiliki tugas mengurus pasien sehari-hari, mulai dari membantu bangun dari tempat tidur, menyuapi makanan, memakaikan baju, membantu ke toilet atau buang hajat, memandikan, hingga mengadministrasikan obat pada pasien, disamping tugas harian rumah tangga, seperti membersihkan rumah, berbelanja kebutuhan sehari-hari, membiayai perawatan kesehatan pasien, dan mengatur keuangan keluarga (Brodaty \& Green, 2002; Chaudhuri \& Das, 2006; Alzheimer's Association, 2018). Mengalami kelelahan adalah masalah utama yang dirasakan oleh pendamping Selain itu, 
mereka pun merasa depresi, mengalami berbagai masalah kesehatan, kurang memiliki waktu luang, memiliki keterbatasan waktu untuk merawat diri sendiri serta bersosialisasi (Peña-Longobardo \& Oliva-Moreno, 2015).

Merawat anggota keluarga dengan kondisi kronis berpotensi memunculkan dampak negatif, tetapi juga tidak menutup kemungkinan untuk membawa dampak positif pula (Lloyd dkk., 2016; Sullivan \& Miller, 2015; Van Wijngaarden dkk., 2018; Yu dkk., 2018). Di sisi lain, proses merawat pasien demensia memunculkan perasaan kebersamaan dalam mengahadapi situasi sulit (Yu dkk., 2018; Van Wijngaarden dkk., 2018). Dalam jangka panjang, kebersamaan ini dapat meningkatkan keterikatan antara pendamping dan pasien. Emosi positif, misalnya kepuasaan, dapat muncul karena pendamping mampu melakukan berbagai tugas perawatan, mendapatkan apresiasi dari pasien dan hubungan antara keduanya menjadi lebih dekat. Pengalaman sebagai pendamping yang kompleks dapat dimaknai secara positif, negatif, atau justru menimbulkan dilema tersendiri karena emosi negatif dan positif bisa hadir pada saat yang bersamaan. Sebagai contoh, pendamping bisa merasa kesal kepada pasien karena pasien sulit untuk diatur tetapi di sisi lain pendamping merasakan kedekatan dengan pasien karena menghabiskan sebagian besar waktu bersama.

Hal-hal yang dialami oleh pendamping ketika menilai pengalaman hidupnya merawat pasien demensia berkaitan dengan konsep kesejahteraan psikologis subjektif, yaitu evaluasi kognitif dan afektif individu mengenai kehidupan seseorang (Diener dkk., 2002). Berdasarkan konsep kesejahteraan subjektif, evaluasi kognitif merupakan penilaian kepuasan hidup individu yang didasarkan pada standar masing-masing individu. Evaluasi afektif meliputi perasaan yang dialami, termasuk seberapa sering kemunculannya. Setiap individu memiliki kondisi kehidupan yang berbedabeda, sehingga seseorang dapat menentukan apakah hidupnya memuaskan berdasarkan apa yang terjadi dalam hidupnya (Diener dkk., 1998). Tingkat kesejahteraan seseorang didasarkan pada evaluasi subjektif mengenai hidupnya (Diener \& Ryan, 2009). Seseorang dengan tingkat kesejahteraan subjektif yang tinggi akan mengalami lebih banyak afek positif dibandingkan afek negatif serta secara keseluruhan puas dengan kehidupannya (Diener dkk, 2002; Maddux, 2018).

Mengingat beban yang dialami pendamping keluarga dalam merawat pasien demensia, peran pendamping dapat dilihat sebagai kejadian yang menimbulkan stres bagi anggota keluarga (Glasdam dkk., 2010; Hashimoto dkk., 2017; Pinquart \& Sörensen, 2004; Singh \& Dubey, 2016). Mereka seringkali mengorbankan kebutuhan dan kesejahteraan dirinya sendiri untuk memberikan perawatan bagi pasien demensia (Tremont, 2011). Penelitian-penelitian sebelumnya menemukan bahwa anggota keluarga yang menjadi pendamping pasien dengan penyakit kronis (demensia, kanker dan disabilitas) 
memiliki kesejahteraan subjektif yang rendah (Graham dkk., 2017; Hajek \& König, 2016; Hammond dkk., 2014; Shakeel dkk., 2015; Van den Berg dkk., 2014). Penurunan fungsi kognitif dan gangguan fungsional yang diderita pasien demensia secara negatif memengaruhi kesejahteraan subjektif pendamping seiring berjalannya waktu (Perren dkk., 2006).

Penelitian mengenai kesejahteraan subjektif berfokus pada evaluasi subjektif dan perasaan seseorang tentang kehidupan dibandingkan dengan kondisi objektif kehidupannya (Maddux, 2018). Kata "subjektif" dalam konsep kesejahteraan subjektif mengacu pada evaluasi kehidupan dari sudut pandang orang itu sendiri. Beberapa penelitian sebelumnya tentang kesejahteraan subjektif pada populasi pendamping keluarga yang merawat pasien dengan kondisi kronis menggunakan metode kuantitatif dan mengandalkan self-reported questionnaires yang terbukti reliabilitas dan validitasnya, seperti Personal Wellbeing Index, Satisfaction with Life Scale dan Positive and Negative Affect Schedule (Fianco dkk, 2015; Graham dkk, 2017; Hajek \& König, 2016; Hamama \& Sharon, 2013; Pinquart \& Sörensen, 2004).

Terlepas dari kuatnya bukti properti psikometrik instrumen tersebut, para peneliti, baik di dalam dan luar bidang psikologi memiliki skeptisisme terhadap metode self-report dalam pengukuran konsep kesejahteraan subjektif (Lucas \& Baird, 2006). Pada saat mengisi kuesioner, beberapa orang mungkin membohongi diri sendiri terkait kondisi kesejahteraannya dan enggan memberikan jawaban yang jujur. Schwarz dan Strack (1999) menjelaskan bahwa makna pertanyaan dalam kuesioner dapat bervariasi tergantung pada konteks yang diberikan sehingga menghasilkan jawaban yang beragam dalam konteks yang berbeda. Melihat konsep kesejahteraan subjektif yang terbatas pada evaluasi subjektif dari kehidupan seseorang, terdapat kemungkinan untuk mempertimbangkan alternatif lain dalam menilai kesejahteraan seseorang (Diener dkk., 2018).

Metode kualitatif dan teknik wawancara terstruktur dinilai cocok untuk menggambarkan kesejahteraan subjektif pendamping karena dapat berfokus untuk memahami pengalaman pendamping. Pada penelitian kualitatif, peneliti menggali informasi dari sudut pandang partisipan yang memberikan informasi detail tentang diri partisipan sebagai subjek (Queirós dkk., 2017). Peneliti dapat melihat evaluasi kehidupan dari sudut pandang partisipan yang memberikan informasi detail tentang diri mereka sebagai pendamping. Teknik wawancara dalam metode kualitatif yang bersifat terbuka memungkinkan partisipan untuk memberikan penilaian tentang kehidupan berdasarkan standar pribadi dan mengeksplorasi berbagai perasaan yang dialami sesuai pengalamannya sendiri. 
Di Indonesia, ikatan keluarga dapat memengaruhi bagaimana pasien demensia mendapatkan perawatan, terlihat dari kecenderungan anggota keluarga mengemban tugas untuk merawat anggota keluarganya yang sakit (Kristanti dkk., 2018). Penelitian ini penting dilakukan dalam konteks Indonesia, mengingat adanya ekspektasi budaya yang berlaku di Indonesia di mana anak diharapkan memenuhi kewajibannya kepada orang tua dengan mengurus dan merawat orang tuanya, terutama jika orang tuanya telah pensiun dan lanjut usia (Beard \& Kunharibowo, 2001; Keasberry, 2001). Selain itu, peran merawat dan mengurus orang tua lebih ditekankan pada anak perempuan (Keasberry, 2001). Ekspektasi budaya yang kuat bagi perempuan untuk mengurus orang tuanya yang berusia lansia dapat berdampak terhadap terhambatnya ambisi beberapa perempuan untuk berkeluarga (Himawan, 2020). Peran merawat dan mengurus orang tua dipandang sebagai takdir bagi anak perempuan yang sudah sepatutnya diterima tanpa keraguan dan tidak dipertanyakan (Tumanggor, 2020).

Setiap budaya memiliki sistem kepercayaan dan ekspektasi masing-masing mengenai hubungan antara anak dan orang tua yang dapat memengaruhi relasi antara keduanya ketika orang tua jatuh sakit. Melihat adanya pengaruh ikatan keluarga dan ekspektasi budaya terhadap peran anak untuk merawat orang tua, terutama pada anak perempuan, dan beban psikologis yang berkaitan dengan kesejahteraan subjektif pendamping, penelitian ini dapat meningkatkan pemahaman tentang perawatan pasien demensia dari perspektif pendamping keluarga dalam konteks Indonesia. Oleh karena itu, tujuan penelitian ini adalah mengetahui gambaran kesejahteraan subjektif perempuan dewasa yang merawat orang tua dengan demensia yang terdiri dari evaluasi kognitif dan afektif atas pengalaman mereka sebagai pendamping.

\section{METODE}

\section{Partisipan}

Studi ini dilakukan di Kota Bandung dengan alasan pada saat penelitian ini berlangsung, peneliti sedang berdomisili di Kota Bandung, sehingga mempermudah proses pengambilan data. Penelitian ini melibatkan empat orang partisipan. Kriteria inklusi partisipan penelitian adalah: 1). anak perempuan yang menjadi pendamping pasien dengan demensia; 2). berusia lebih dari 18 tahun; dan 3). telah sedang merawat pasien demensia minimal 6 bulan. Kriteria eksklusi partisipan adalah: 1). mendapatkan kompensasi berupa uang dari kegiatan merawat pasien; 2). pasien yang dirawat sudah meninggal; 3). pasien yang dirawat mengalami kondisi medis primer lain selain 
demensia; dan 4). pasien yang dirawat mengalami demensia sebagai akibat dari komplikasi penyakit lain. Kriteria inklusi partisipan tidak dibatasi oleh karakteristik demografi tertentu (status pernikahan). Partisipan direkrut melalui metode purposive sampling.

Penjaringan responden dilakukan menggunakan survei daring dalam bentuk Google Form yang disebarkan melalui media sosial dan meminta bantuan peneliti lain yang sebelumnya pernah meneliti topik yang serupa untuk menyebarkan tautan survei kepada partisipan penelitiannya terdahulu. Penentuan partisipan penelitian tetap dilakukan oleh peneliti dengan menyesuaikan karakteristik calon partisipan dengan kriteria inklusi. Sebanyak tujuh calon partisipan berhasil direkrut, tetapi tiga diantaranya mengundurkan diri. Satu orang diketahui sudah tidak lagi menjadi pendamping karena anggota keluarganya yang mengalami demensia sudah meninggal, satu orang menyatakan terlalu sibuk sehingga tidak dapat berpartisipasi, sedangkan satu orang lainnya tidak memenuhi kriteria inklusi karena bukan pendamping pasien demensia. Oleh karena itu, jumlah partisipan penelitian ini adalah empat orang. Rincian karakteristik partisipan dapat dilihat dalam Tabel 1.

Tabel 1.

Karakteristik Partisipan

\begin{tabular}{|c|c|c|c|c|}
\hline Identitas Responden & P1 & $\mathbf{P 2}$ & P3 & P4 \\
\hline Usia & 60 tahun & 30 tahun & 54 tahun & 52 tahun \\
\hline Status pernikahan & menikah & menikah & menikah & menikah \\
\hline Pendidikan & $\begin{array}{l}\text { perguruan } \\
\text { tinggi }\end{array}$ & perguruan tinggi & perguruan tinggi & perguruan tinggi \\
\hline Pekerjaan & pensiunan & pegawai swasta & ibu rumah tangga & ibu rumah tangga \\
\hline $\begin{array}{c}\text { Status pasien yang } \\
\text { dirawat }\end{array}$ & Ibu & Ayah & $\mathrm{Ibu}$ & Ayah \\
\hline Durasi merawat & 6 tahun & 4 tahun & 10 tahun & 2 tahun \\
\hline
\end{tabular}

\section{Desain}

Metode penelitian yang digunakan adalah kualitatif dengan desain studi kasus. Studi kasus adalah penjelasan dan analisis secara mendalam mengenai individu, kelompok, atau kejadian (Christensen, 2010). Tujuan studi kasus adalah untuk memberikan gambaran secara mendetail tentang latar belakang, sifat, serta karakter yang khas dari kasus, ataupun status dari individu, yang kemudian dijadikan suatu hal yang bersifat umum. Teknik pengambilan data menggunakan wawancara semi terstruktur. Strategi yang dilakukan oleh peneliti untuk menjaga keabsahan data 
adalah menggunakan thick description, yaitu menuliskan deskripsi mendalam ketika memaparkan hasil wawancara (Creswell, 2009).

\section{Prosedur}

Persetujuan etik untuk penelitian ini telah diperoleh dari Komite Etika Penelitian Universitas Padjadjaran, Jawa Barat. Proses penjaringan partisipan dilakukan secara daring menggunakan Google Form. Formulir meliputi: 1). rincian kontak partisipan yang terdiri dari nama, usia dan nomor telepon; 2). pertanyaan terbuka untuk memastikan apakah calon partisipan memenuhi kriteria inklusi partisipan penelitian yaitu status hubungan dengan pasien dan durasi merawat anggota keluarga dengan demensia; dan 3). kesediaan untuk dihubungi lebih lanjut untuk keperluan penelitian. Tautan yang merujuk ke formulir registrasi disebarkan melalui media sosial, yaitu Facebook, Instagram, Whatsapp, dan Line, serta ke berbagai grup media sosial lainnya, seperti grup organisasi, pekerjaan, pertemanan, atau melalui percakapan daring personal. Calon partisipan yang sesuai kriteria bisa mendaftarkan diri melalui tautan formulir registrasi untuk dihubungi kembali. Seluruh calon partisipan yang terjaring dihubungi oleh peneliti melalui Whatsapp. Dalam kontak ini, peneliti memperkenalkan diri, menjelaskan alasan menghubungi, memberikan gambaran singkat penelitian, dan mengundang untuk berpartisipasi dalam penelitian. Selanjutnya, dibuat jadwal pelaksanaan wawancara dengan calon partisipan yang menyatakan kesediannya untuk menjadi partisipan. Peneliti menyerahkan keputusan mengenai jadwal dan lokasi pengambilan data kepada partisipan. Hal ini dilakukan dengan pertimbangan kenyamanan calon partisipan.

Pada saat pertemuan pengambilan data, peneliti membuka sesi dengan perkenalan kembali. Setelah itu, dimulai proses pengisian informed consent. Proses ini dimulai dengan peneliti memberikan penjelasan rinci tentang: 1). penelitian yang dilakukan meliputi latar belakang penelitian, tujuan, prosedur, dan durasi pengambilan data; 2). manfaat dan resiko penelitian; 3). jaminan kerahasiaan data; dan 4). hak partisipan untuk mengundurkan diri kapan saja dari penelitian ini. Setelah penjelasan diberikan, partisipan memperoleh kesempatan bertanya terkait informasi tersebut atau jika ada hal lain yang ingin diketahui partisipan namun belum disampaikan oleh peneliti. Setelah itu, partisipan menandatangani lembar informed consent sebagai bentuk kesediaannya menjadi partisipan. Informed consent ditandatangani juga oleh peneliti sebagai bentuk kesepakatan.

Ketika proses pengambilan data dimulai, partisipan terlebih dahulu mengisi data demografis, meliputi usia, status pernikahan, tingkat pendidikan, dan pekerjaan. Peneliti meminta izin terlebih dahulu untuk merekam percakapan selama wawancara untuk memastikan tidak ada informasi yang 
tertinggal. Selanjutnya dilakukan wawancara dengan menggunakan panduan wawancara yang sudah disusun sebelumnya. Wawancara berlangsung selama 30 sampai 45 menit. Setelah wawancara selesai, partisipan menerima buah tangan sebagai bentuk apresiasi dalam keterlibatannya dalam penelitian.

\section{Instrumen}

Instrumen yang digunakan dalam penelitian ini adalah panduan wawancara semi terstruktur untuk menggali kesejahteraan subjektif (subjective well-being) (Diener dkk., 2002). Panduan wawancara dikembangkan berdasarkan penalaran deduktif di mana peneliti mencari subyek yang telah ditentukan sebelumnya dan menguji hipotesis atau teori (Bengtsson, 2016). Pengembangan panduan wawancara ini dibagi menjadi tiga langkah, yaitu identifikasi aspek-aspek yang membangun kesejahteraan subjektif, mengembangkan indikator bagi masing-masing aspek, dan terakhir, mengembangkan pertanyaan utama. Seluruh pertanyaan dalam panduan wawancara bersifat terbuka. Peneliti menggunakan kata-kata seperti "Silahkan gambarkan...", "Silahkan ceritakan...”, “Apa yang membuat Anda...", dan "Bagaimana pandangan Anda...". Pertanyaan probing disesuaikan dengan jawaban partisipan terhadap pertanyaan sebelumnya.

Telah disebutkan sebelumnya bahwa kesejahteraan subjektif didefinisikan sebagai evaluasi kognitif dan afektif individu mengenai kehidupannya (Diener dkk., 2002). Berdasarkan definisi tersebut dan kajian literatur yang ada, teridentifikasi dua aspek kesejahteraan subjektif, yaitu evaluasi kognitif dan evaluasi afektif. Evaluasi kognitif individu atas kehidupannya mencerminkan perbandingan antara kondisi kehidupan saat ini dengan apa yang dianggap sebagai standar yang sesuai (Diener dkk., 1985). Oleh karena itu, evaluasi kognitif dibagi menjadi dua bagian, yaitu gambaran kehidupan yang ideal dan gambaran kehidupan saat ini. Di sisi lain, evaluasi afektif mengacu pada penilaian seseorang mengenai frekuensi dan intensitas dari berbagai emosi yang dialami (Eid \& Diener, 2004). Maka, evaluasi afektif dibagi menjadi beberapa bagian, yaitu perasaan yang dirasakannya selama menjadi pendamping, pemicu munculnya suatu perasaan, frekuensi perasaan, dan intensitas perasaan tersebut. Selanjutnya pertanyaan-pertanyaan utama dalam panduan wawancara dikembangkan untuk menggali bagian-bagian tersebut. Contoh pertanyaan dapat dilihat dalam Tabel 2. 
Tabel 2.

Panduan Wawancara

\begin{tabular}{|c|c|c|c|}
\hline Aspek & Bagian & Contoh Pertanyaan Utama & Contoh Pertanyaan Probing \\
\hline \multirow[t]{2}{*}{$\begin{array}{l}\text { Evaluasi } \\
\text { kognitif }\end{array}$} & $\begin{array}{l}\text { Gambaran } \\
\text { kehidupan yang } \\
\text { ideal }\end{array}$ & $\begin{array}{l}\text { Sebagai seseorang yang } \\
\text { mendampingi dan merawat anggota } \\
\text { keluarga dengan demensia, } \\
\text { bagaimana Anda menggambarkan } \\
\text { kehidupan yang ideal? }\end{array}$ & $\begin{array}{l}\text { Apakah gambaran kehidupan } \\
\text { yang ideal sama dengan } \\
\text { gambaran kehidupan saat ini? }\end{array}$ \\
\hline & $\begin{array}{l}\text { Gambaran } \\
\text { kehidupan saat ini }\end{array}$ & $\begin{array}{l}\text { Bagaimana pandangan Anda } \\
\text { mengenai gambaran kehidupan } \\
\text { selama merawat anggota keluarga } \\
\text { dengan demensia sampai saat ini? }\end{array}$ & $\begin{array}{l}\text { Jika terdapat perbedaan } \\
\text { gambaran mengenai } \\
\text { kehidupan, Apa yang membuat } \\
\text { perbedaan itu terjadi? } \\
\text { Bagaimana Anda } \\
\text { menanggapinya? }\end{array}$ \\
\hline \multirow[t]{3}{*}{$\begin{array}{l}\text { Evaluasi } \\
\text { afektif }\end{array}$} & $\begin{array}{l}\text { Perasaan yang } \\
\text { dirasakannya selama } \\
\text { menjadi pendamping }\end{array}$ & $\begin{array}{l}\text { Berdasarkan kondisi dan peran Anda } \\
\text { saat ini, silahkan ceritakan perasaan } \\
\text { apa saja yang muncul selama } \\
\text { merawat anggota keluarga. }\end{array}$ & \\
\hline & $\begin{array}{l}\text { Pemicu munculnya } \\
\text { suatu perasaan }\end{array}$ & $\begin{array}{l}\text { Apa yang membuat Anda merasakan } \\
\text { perasaan-perasaan tersebut? } \\
\text { (Sebutkan seluruh jawaban yang } \\
\text { diungkapkan oleh partisipan) }\end{array}$ & \\
\hline & $\begin{array}{l}\text { Frekuensi perasaan } \\
\text { tersebut dan } \\
\text { intensitas perasaan } \\
\text { yang dirasakannya }\end{array}$ & $\begin{array}{l}\text { Seberapa sering Anda merasakan } \\
\text { perasaan-perasaan itu? (Sebutkan } \\
\text { seluruh jawaban yang diungkapkan } \\
\text { oleh partisipan) }\end{array}$ & \\
\hline
\end{tabular}

\section{Teknis Analisis}

Data yang dianalisis adalah verbatim dari rekaman hasil wawancara. Teknik analisis kualitatif yang digunakan adalah analisis konten. Jenis analisis konten yang dipilih adalah analisis laten di mana peneliti mendalami data untuk mengidentifikasi makna tersembunyi dalam teks. Dalam analisis konten, unit analisis yang digunakan adalah pernyataan-pernyataan yang disampaikan oleh setiap partisipan. Proses analisis konten terbagi ke dalam empat tahap, yaitu: 1). dekontekstualisasi; 2). rekontekstualisasi; 3). kategorisasi; dan 4). kompilasi (Bengtsson, 2016). Pada tahap dekontekstualisasi, seluruh verbatim dibaca terlebih dahulu untuk meningkatkan familiaritas terhadap data yang ada sebelum memecah data menjadi unit makna kecil (kode). Penentuan kode dilakukan dengan memberikan label tertentu pada pernyataan-pernyataan partisipan. Tahap kedua adalah rekontekstualisasi, di mana kode-kode yang muncul diperiksa kembali untuk memastikan apakah kode sudah tepat dalam merefleksikan data dan sesuai dengan dua aspek kesejahteraan subjektif, yaitu evaluasi kognitif dan afektif. Verbatim dan daftar kode dibaca secara berulang dan berkala untuk membandingkan hasil coding dengan transkrip verbatim. Pada tahap kategorisasi, kategori dan tema 
diidentifikasi. Kode-kode yang serupa dan berkaitan digabungkan, lalu kode tersebut dikelompokkan ke dalam unit makna yang lebih besar, yaitu kategori yang mencakup semua informasi relevan sesuai dengan bagian-bagian dari evaluasi kognitif dan evaluasi afektif. Selanjutnya, kategori digabungkan menjadi tema. Setelah itu, tahap kompilasi, meliputi identifikasi makna dalam teks dan menuliskan kutipan langsung dari transkrip verbatim untuk menjelaskan tema dan beberapa kategori yang berisi kode-kode dari unit analisis. Identifikasi kode, kategori, dan tema dibahas secara berkala bersama dengan tim peneliti sampai memperoleh kesepakatan tentang tema. Analisis pada tahap satu dan dua dilakukan oleh satu orang sedangkan tahap tiga dan empat dilakukan oleh tiga orang.

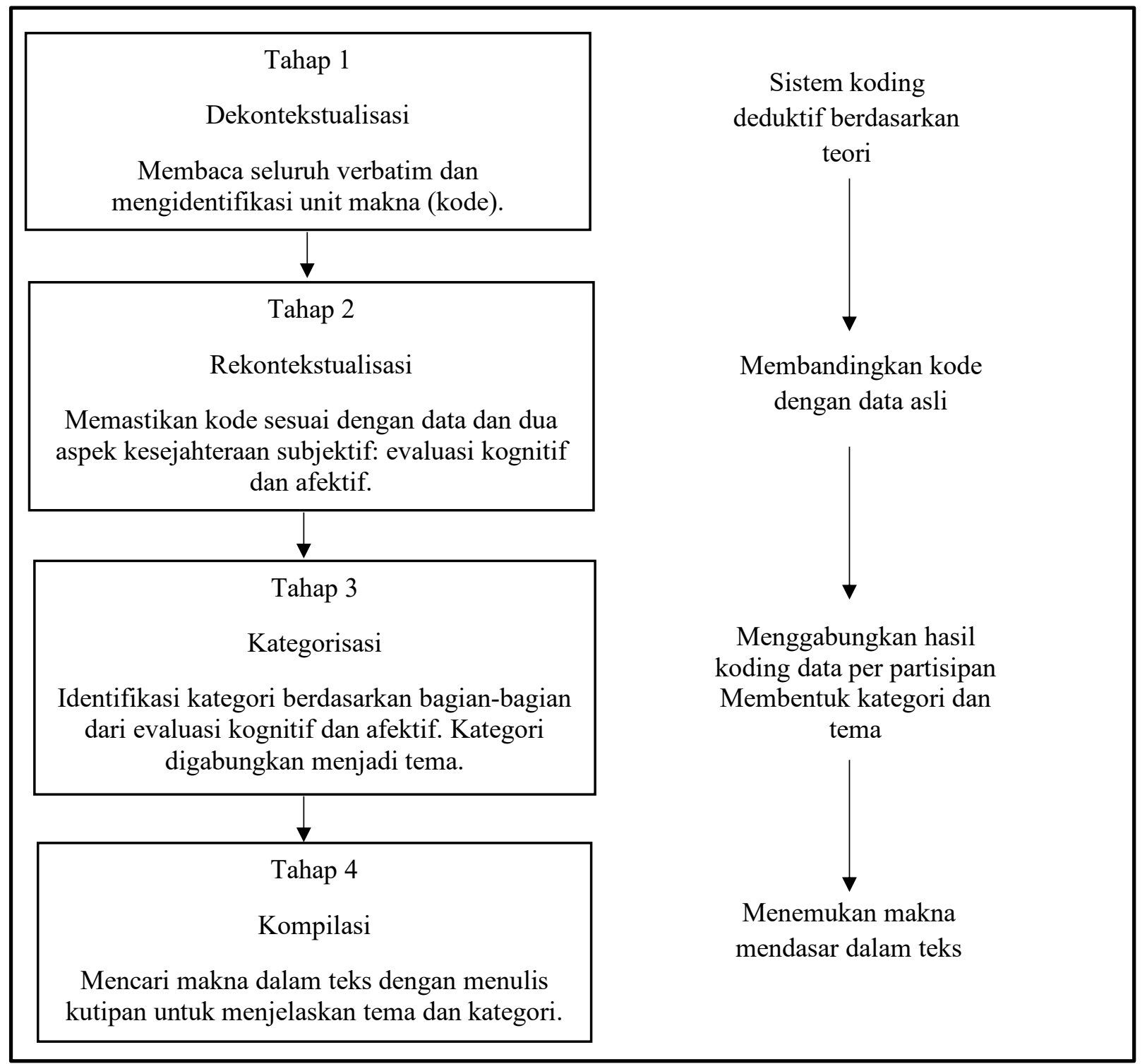

Figur 1. Tahapan Analisis Laten 


\section{ANALISIS DAN HASIL}

Evaluasi kognitif dan afektif terdiri dari beberapa kategori yang menggambarkan bagaimana pendamping menilai kehidupannya. Bagian evaluasi kognitif terdiri dari dua tema dan beberapa kategori, yaitu: 1). gambaran standar kehidupan yang ideal; 2). gambaran kehidupan saat ini; dan 3). perubahan dan penerimaan gambaran kehidupan yang baru. Bagian evaluasi afektif terdiri dari kategori yang menjelaskan perasaan-perasaan yang sering dirasakan oleh pendamping beserta paparan mengenai pengalaman tersebut.

\section{Evaluasi Kognitif}

Evaluasi kognitif mengacu pada penilaian kepuasan hidup seseorang yang didasarkan pada standar masing-masing individu. Di dalam suatu keluarga, jika terdapat salah satu anggota keluarga yang sakit, maka dapat berdampak kepada anggota keluarga lainnya. Penilaian mengenai kepuasan hidup bergantung pada perbandingan antara keadaan diri saat ini dengan kondisi yang dianggap ideal. Untuk mengetahui kepuasan hidup pendamping, peneliti meminta partisipan melihat apakah gambaran kehidupan ideal sama dengan gambaran kehidupan saat ini. Dua partisipan (P2 dan P4) menyatakan bahwa gambaran kehidupan ideal dan gambaran kehidupan saat ini tidak berbeda. Sementara itu, dua partisipan lainnya (P1 dan P3) menyatakan bahwa kondisi kehidupan saat ini berbeda dengan gambaran kehidupan ideal. Perbedaan antara gambaran kehidupan ideal dengan kondisi kehidupan sekarang membuat kedua partisipan melakukan upaya untuk merubah gambaran kehidupan dan menerima kondisi kehidupan saat ini. Dua tema yang muncul adalah pengaturan tinggal bersama (living arrangement, manajemen keluarga) dan relasi sosial dengan pasien.

\section{Pengaturan Tinggal Bersama}

Kehidupan pendamping saling berkaitan antara keinginan pribadi dan juga keikutsertaan anggota keluarga di dalamnya. Tema pengaturan tinggal bersama atau manajemen keluarga mendeskripsikan bagaimana partisipan mengatur kehidupannya sendiri dan kehidupan bersama anggota keluarga lainnya selama merawat pasien. Bagi P3, gambaran kehidupan ideal adalah ketika keluarganya dapat tinggal terpisah dari pasien. Masing-masing keluarga seharusnya memiliki privasi dan dapat tinggal di rumah sendiri.

Idealnya itu, keluarga itu kan misah. Satu keluarga itu punya privasi sendiri-sendiri ya, rumah sendiri segala macem. Idealnya begitu kalau saya mau. 
Sementara, P4 menjelaskan gambaran kehidupan ideal adalah selama pasien dapat dirawat serta saudara-saudara kandung yang lain tetap datang berkunjung secara rutin untuk menengok pasien. Harapannya, pasien tetap ada yang menemani dan membantu karena kondisinya sudah semakin melemah.

Kita rawat yang ada aja. Kakak-kakak bergantian juga nengokin bapak, jadi minggu ini siapa datang ke Bandung, nanti minggu depan ada yang datang juga. Harapan saya sih ada yang nemenin bapak. Karena, ya, itu karena ayahku udah semakin lemah aja ya, menurun aja ya kemampuannya. Kalau orang kemampuan sudah menurun kan kita harapkan ada yang menolong ya.

P3 menyatakan bahwa kondisi kehidupannya sekarang berbeda dengan gambaran kehidupan ideal, yaitu bisa tinggal terpisah dari orang tua di rumah sendiri. Saat ini P3 mengikuti keinginan pasien untuk tinggal bersama di satu rumah. Selain tinggal bersama pasien, ia juga tinggal bersama anggota keluarga lainnya, yaitu keluarga saudara kandung (berserta pasangan dan anak-anaknya).

Sesuai dengan keinginan ibu. Saya dulu tinggal di Jatihandap. Setelah bapak saya meninggal, ibu saya nyuruh saya tinggal di sini. Nah, jadi ibu itu harus selalu di sini sama orang-orang. Jadi gamau sendirian gitu. Harus selalu ada orang Kalau keinginan saya enggak sebetulnya ya.

P4 menilai kondisi kehidupannya sekarang sama dengan gambaran kehidupan ideal, yaitu dapat merawat pasien dan sanak saudara yang berada di luar kota tetap menunjukkan kepedulian dengan datang mengunjungi pasien. Sampai sekarang, kondisi kehidupan saat ini sama dengan gambaran kehidupan ideal karena saudara yang lain menengok pasien secara rutin. Walaupun pada waktu tertentu, P4 dan saudara lainnya tidak bisa mememani pasien, pasien tetap ditemani oleh asisten rumah tangga.

Sampai saat ini sih saya rasa ideal-ideal aja ya. Maksudnya kakak-kakak juga tetep perhatian ke bapak. Mereka bergantian nengokin bapak, jadi minggu ini siapa datang ke Bandung, nanti minggu depan ada yang datang juga. Walaupun mereka hanya sehari-dua hari. Kadang aku seharian, dua harian, tiga harian tuh nggak nengok bapak. Tapi selama ada Pak Mail, Mbak Iroh (asisten rumah tangga) ataupun kakak-kakak. Nah aku merasa 'Oh yaudah nggak apa-apa, bapak ada temennya. 
Seiring berjalannya waktu, P4 menerima dan memaklumi kondisi pasien. P4 memutuskan untuk menjalani kondisi yang saat ini dihadapi. Hal ini mendemonstrasikan kemampuan menyesuaikan diri P4 untuk bisa beradaptasi dengan situasi baru.

Setelah berjalannya waktu ya, ternyata setelah kami pelajari, kami menerima dan memaklumi bahwa memang seperti itu kan. Jadi aku lebih 'nggak apa-apalah, ya udah memang seperti ini kondisinya, kita jalani aja'. Menuju perubahan itu kan pasti ada ya, istilahnya kita masih cari-cari kesesuaian dengan situasi yang baru.

P3 mendeskripsikan gambaran kehidupan yang baru dengan memfokuskan perhatian pada kenyamanan pasien, yaitu selama pasien bisa merasa nyaman dan keadaannya semakin membaik.

Selama ibu saya nyaman, selama ibu saya keadaannya lebih baik. ini ideal buat ibu saya. Ya biar ajalah.

Walaupun P3 mengatakan bahwa dirinya akan mengikuti permintaan pasien dan melihat kondisi ideal adalah yang sesuai dengan keinginan pasien, partisipan menemukan kesulitan untuk menerima kondisi kehidupannya saat ini. Caranya untuk menerima kondisi kehidupan yang tidak sesuai dengan gambaran kehidupan ideal adalah dengan mencoba berdamai dengan keadaan. Cara ini disampaikan berkali-kali oleh partisipan.

Ya berdamai dengan keadaan aja. Kalau ga berdamai stres juga saya. Ya berdamai dengan keadaan aja. Iya. Ya walaupun bukan yang saya, ya jalani aja itu udah. Ga terlalu inilah saya mah. Mau ini itu engga. Ya berdamai denga keadaan, ya betul kan. Jadi, menyesuaikan dengan keadaan yang sekarang saya hadapi udah. Makanya saya bilang saya mau berdamai dengan keadaan aja.

P3 juga menyatakan bahwa dirinya harus menerima apa pun yang terjadi karena satu-satunya cara untuk menghadapi situasi ini adalah dengan menerimanya secara penuh dan mengganggap bahwa kondisi sekarang adalah kondisi yang paling ideal.

Ya harus menerima. Ya soalnya setiap keinginan orang-orang pasti beda-beda. Tidak banyak pikiran deh gitu. Itu aja udah. Kalau ga menerima, mau apa lagi. Mau gimana? Makanya saya bilang, saya ada di kondisi ini, saya anggap ini kondisi yang paling ideal untuk saat ini. 
Pernyataan partisipsan merefleksikan rasa "keputusasaan" yang disebabkan oleh berubahnya kondisi kehidupan karena pasien jatuh sakit. Apa yang dipaparkan P3 mengesankan bahwa sesungguhnya terdapat ketidakrelaan untuk menerima kondisi kehidupan yang tidak ideal. Kesulitan partisipan untuk menerima kondisi kehidupan saat ini disembunyikan dengan penggunaan pernyataan "mau bagaimana lagi?" dan pengulangan pernyataan "berdamai dengan keadaan". "Keharusan untuk menerima" menjadi satu-satunya cara yang bisa dilakukan untuk menghadapi kondisi ini dapat dijelaskan sebagai keterpaksaan untuk menangani situasi di luar harapan. Upaya ini dilakukan untuk meyakinkan diri sendiri bahwa ia memang sudah "menerima" kondisi kehidupan saat ini. Kecenderungan ini mungkin dapat dijelaskan dari pernyataan partisipan selanjutnya mengenai pandangan bahwa merawat orang tua itu tidak ada batasnya karena dapat menjadi pintu surga bagi anak sehingga apa pun yang terjadi harus tetap dijalani. Pandangan ini berasal dari kajian agama, perkataan teman dan ustaz.

Bahwa merawat orang tua itu gak ada batasnya sampai kapanpun. Salah satu pintu surga anak itu merawat orang tua. Dari apa ya, dari ilmu yang saya pelajari mungkin ya. Dengar dari beberapa kajian, dari teman, dari ustaz juga, jadi merawat orang tua itu ga ada batasnya gitu. Dan saya coba terapkan itu.

\section{Relasi Sosial dengan Pasien}

Tema relasi sosial dengan pasien mendeskripsikan relasi yang terjalin antara partisipan dan pasien serta dinamika hubungan tersebut selama merawat pasien. Bagi P1, gambaran kehidupan ideal adalah ketika dirinya bisa melakukan aktivitas bersama dengan pasien yaitu pergi bersama dan mengobrol.

Yang tadi yang ibu bilang bahwa ya ... asik juga. Kita bisa ke mana. Pengennya Ibu itu menjadi tempat bertanya... Ya bisa ngobrol lah, gitu, masih mengobrol.

Sementara itu, P2 mendeskripsikan gambaran kehidupan ideal adalah dengan memiliki kesiapan dan bisa kuat baik secara fisik maupun psikologis untuk menghadapi situasi ketika pasien jatuh sakit.

Menurut saya sih seharusnya lebih siap secara fisik dan psikologis, artinya harus lebih sehat, harus lebih...tough gitu ya walau idealnya saya seharunya lebih kuat 
harus lebih sehat gitu, tapi secara fisik lebih lelah juga. Harapannya seharusnya itu lebih kuat secara psikologis maupun fisik.

P2 menyatakan bahwa jika pendamping bisa membawa diri lebih positif ketika merawat pasien, maka sikap dan perasaan positif pendamping bisa membuat pasien lebih semangat. Pasien diharapkan dapat merasa lebih positif, walaupun kondisinya sedang sakit. Terdapat keinginan untuk tidak terlihat lemah di depan pasien.

Ketika pendampingnya itu lebih positif itu akan membantu... pasien untuk lebih semangat lebih positif, karena saya ngalamin sendiri ketika saya nya, jadi gini, pada saat posisi ayah saya sedang sakit itu, saya di rumah bersama ibu saya. Kalau saya mau tidak mau memposisikan sebagai... saya memback up harus lebih kuat gitu.

P1 menjelaskan bahwa kondisi kehidupannya sekarang berbeda dengan gambaran kehidupan ideal, yaitu bisa mengobrol dan beraktivitas bersama pasien. Gambaran kehidupan ideal tidak dapat tercapai karena kondisi kesehatan pasien yang buruk. Saat ini pasien sudah sulit untuk diajak bicara dan saat diajak berkomunikasi responnya tidak sesuai. Selain itu, pasien pun menunjukkan gejala emosional seperti mengamuk, menangis dan merasa murung. Memulai pembicaraan dan mengajak mengobrol bersama pasien sudah sulit untuk dilakukan. Pasien terlihat bingung ketika diajak berkomunikasi.

Jadi pas itu, jadi itu mulai tidak bisa diajak bicara. Maksudnya tidak connect diajak komunikasi. Saya pikir ini mungkin kesadarannya memang ngaco. Yang ngamukngamuk itu. Akhir-akhir ini kadang-kadang gak jelas. Baperan gitu. Maksudnya, ngamuk, nangis, murung. Saya tanya, "Mau kemana?" Dia gak tau mau kemana. Terus orang jalan aja udah susah, saya bilang, "Apa nanti gak jatuh?" "Mau kemana?". Pokoknya mau keluar. Nangis, gerung-gerung.

Pada awalnya, P2 menyatakan bahwa ia memiliki kekhawatiran apakah dirinya bisa menjalani kehidupan seperti gambaran kehidupan ideal.

Yang standar ideal mungkin saya terlalu khawatir akan begini-begini jadi saya bisa nggak untuk mencapai kondisi ideal yang saya ingin harus saya kuat harus saya sigap seperti itu. 
Walaupun pada awalnya merasa khawatir mengenai kemampuan untuk mencapai kondisi ideal, gambaran kehidupan saat ini tidak berbeda dengan gambaran kehidupan ideal. P2 mampu untuk lebih siap secara fisik dan psikologis untuk merawat pasien. Ia mampu mengurangi rasa khawatir karena mendapatkan dukungan dari lingkungan sosialnya, yaitu pasangan, anggota kelurga lain dan teman.

Sejauh ini bisa, hanya mungkin ada di masa kalau kita terlalu cemas atau terlalu panik untuk mencapai suatu hal itu kan jadi ada momen merasa tidak berdaya, tetapi balik lagi karena kebetulan saya ada di lingkungan yang memberi support dan cukup memberikan back up, jadi sejauh ini bisa.

P1 mendeskripsikan gambaran kehidupan yang baru dengan memfokuskan perhatian pada rasa damai yang dirasakan pasien. Selain itu, partisipan juga berharap pasien bisa beraktivitas. Selama pasien merasa damai, partisipan dapat menerima kondisi kehidupan saat ini. Partisipan pun berusaha untuk mencoba berdamai dengan keadaan dan merubah dirinya sendiri.

Sebenernya yang ideal sekarang juga, buat saya tuh, dia punya aktivitas. Selama dia (Ibu) damai lah, saya terima lah, ya sudah saya mencoba berdamai dengan keadaan. Pokoknya selama beliau damai dengan hidupnya, jadi ya saya ikutin. Saya bilang, mau kayak gimana juga, saya merubah diri saya, merubah standar saya.

Pada awalnya, P1 merasa berat untuk menerima kondisi kehidupan yang berubah karena pasien jatuh sakit. Partisipan menyadari bahwa dirinya tidak bisa membalikkan keadaan seperti dulu lagi dan sudah tidak mungkin untuk mencapai kondisi ideal. Pada akhirnya partisipan mencoba berdamai dengan keadaan dan tidak memasang standar lagi.

Awal-awalnya berat buat saya. Saya menyesal, pokoknya segala macem. Saya gak bisa terima sebenernya. Kesal! Ingin marah! Saya sudah pasrah bagaimana, kalai dulu memasang standar asik juga. Kita bisa kemana masih ngobrol. Maksud saya, saya gak mungkin membalikkan keadaan gitu. Saya pengen ideal seperti itu kan gak mungkin. Ya udah saya mencoba berdamai dengan keadaan. Jadi sudah tidak, saya nggak punya dan nggak masang standar saya.

P1 menyatakan bahwa apa yang dialami adalah takdir yang harus dijalani. Ia pun pasrah dengan kondisi kehidupan saat ini, walaupun sempat membayangkan bagaimana rasanya jika kondisi 
kehidupan ideal tercapai. Tidak ada cara lain yang bisa dilakukan selain menerima. Menyadari fakta bahwa pasien menunjukkan perilaku yang tidak sepantasnya di luar kesadaran membantu partisipan untuk memahami dan menerima kondisi kehidupannya sekarang.

Saya bilang, mungkin ini garis hidup saya, harus jalanin kayak gini. Dan saya bilang, ya memang kita mesti kayak gini kok harus gimana lagi. Mau menyesal juga, apa sih yang mau disesali. Saya bilang, gak ada yang perlu disesali. Karena beliau (Ibu) juga gak mau, mungkin kalo beliau sadar dia gak mau kayak gitu. Tapi saya pikir, ya akhirnya memang saya mencoba, dia kan juga gak sadar, dia begitu. Ya sudah. Saya harus terima. Mestinya begini, ya udah saya lakuin aja deh.

Walaupun sudah berusaha menerima kondisi kehidupan yang tidak ideal, partisipan menyiratkan ambivalensi mengenai hubungan antara orang tua dan anak. Partisipan merasa seperti anak durhaka yang sulit untuk akur dengan pasien. Terkadang partisipan merasa iri dengan relasi orang tua dan anak yang dijalani orang lain. Hubungan yang dimiliki orang lain terlihat baik dan mencerminkan gambaran kehidupan ideal partisipan.

Kok saya merasa seperti anak durhaka. Gak pernah cocok dengan ibu saya. Gak seperti orang dengan ibunya. Maksudny kalau saya bilang sih, hidupnya di satu sisi kadang-kadang saya tuh ngeliat orang lain, kok orang lain enak ya punya ibu tempat bertanya, tempat ngobrol. Orang lain bisa dengan ibunya.

P1 terlihat berusaha keras untuk menerima kondisi kehidupannya saat ini dengan adanya ganjalan. Mulai dari merasa pasrah, mengatakan bahwa tidak ada yang bisa dilakukan untuk merubah keadaan dan tidak menetapkan standar apa pun. Pernyataan-pernyataan partisipan mengesankan adanya keengganan dan ketidakrelaan untuk menerima kondisi yang dihadapi sekarang. Upaya yang dilakukan untuk menenangkan diri sendiri adalah dengan meyakini apa yang terjadi sebagai takdir yang harus dijalani. Usaha keras untuk menerima keadaan dapat terlihat dari penjelasan mengenai perilaku dan perkataan pasien di luar kesadaran. Secara tidak langsung, penjelasan ini digunakan untuk menjustifikasi kenihilan situasi yang dihadapi, sehingga mendorong partisipan untuk mengharuskan dirinya menerima kondisi saat ini. Pada akhirnya partisipan menunjukkan ambivalensi terhadap hubungannya dengan pasien. Seakan jika partisipan mengeluh atau sulit menerima kondisi pasien, maka dirinya sudah pasti dicap sebagai anak durhaka. Partispan hanya bisa berandai-andai untuk bisa mencapai gambaran kehidupan ideal. 


\section{Evaluasi Afektif}

Evaluasi afektif mendeskripsikan perasaan-perasaan yang sering dialami oleh pendamping yang berkaitan dengan aktivitas merawat pasien demensia dan juga seberapa sering mereka merasakan perasaan tersebut. Pertanyaan evaluasi afektif dispesifikan pada pengalaman pendamping selama merawat pasien sehingga peneliti memiliki keterbatasan untuk menjelaskan seberapa besar proporsi pengalaman afek ini dalam dunia afektif individual pendamping. Pertanyaan disusun dengan mempertimbangkan tiga hal yaitu: 1) peran partisipan sebagai pendamping utama, 2) banyaknya waktu yang dihabiskan bersama pasien, dan 3) interaksi sosial partisipan ketika berada di lingkungan sosial yang tidak mengenal dirinya dan pasien. Keempat partisipan tidak sejahtera secara emosional karena perasaan-perasaan yang berhubungan dengan aktivitas perawatan mayoritas negatif. Seluruh perasaan yang diutarakan partisipan adalah perasaan yang tidak menyenangkan seperti rasa kesal, malu, khawatir dan kasihan. Perasaan-perasaan tersebut muncul karena kejadian spesifik yang ditemui selama merawat anggota keluarga dengan demensia.

Perasaan yang sering dialami oleh beberapa pendamping tetapi tidak dialami oleh partisipan lain bukan berarti partisipan itu tidak mengalami perasaan tersebut. Begitu pun dengan perasaan yang hanya dialami oleh satu pendamping. Perasaan-perasaan berikut merupakan perasaan yang berdasarkan hasil analisis sering dialami oleh pendamping pasien demensia ketika melakukan kegiatan merawat. Variasi perasaan antar pendamping bisa muncul karena terdapat perbedaan pengalaman mereka selama merawat pasien demensia. Temuan ini kami sampaikan untuk menunjukkan bahwa kejadian spesifik pasien demensia dapat memunculkan perasaan tertentu. Dengan memaparkan perasaan yang sering dirasakan beberapa pendamping dan perasaan yang hanya sering dialami pendamping tertentu, dapat dilihat kesamaan dan perbedaan evaluasi afektif pendamping pasien demensia. Penjelasan berikut ini dimulai dari perasaan yang sering dialami oleh beberapa partisipan, lalu dilanjutkan ke perasaan yang hanya sering dialami oleh partisipan tertentu.

Tiga partisipan (P2, P3 dan P4) menyatakan sering merasa kesal ketika berinteraksi dengan pasien. Penurunan fungsi kognitif dan perubahan perilaku yang dialami pasien seringkali menjadi pemicu kekesalan pada ketiga pendamping ini. Pemicu kekesalan dapat diperburuk oleh perilaku pasien yang tidak sesuai yang seharusnya, tidak mau percaya, dan tidak mau mengalah layaknya anak kecil, tidak mau menuruti apa yang diminta pendamping, dan komunikasi yang sulit diantara keduanya, seperti lama menanggapi pembicaraan, cepatnya pergantian topik pembicaraan dan sulit memahami apa yang disampaikan. 
P2 merasa kesal dan terkesan tidak sabar dalam menghadapi pasien karena sulit berkomunikasi dan kurang memahami apa yang disampaikan pasien.

Kenapa sih kalau aku komunikasi susah, kalau diajak ngomong ini malah ngeyel, malah membahas apa karena tadi apa belum paham saya, ini ada yang ada yang nggak pas, kelihatannya saya jadi nggak sabar.

Sementara P4 merasa kesal karena apa yang ingin dilakukan pasien seringkali tidak sesuai dengan apa yang sepatutnya dilakukan, seperti mengambil uang pensiun dalam jumlah besar tanpa tahu digunakan untuk apa dan menuduh asisten rumah tangga mencuri uang simpanan padahal lupa menaruhnya di mana. Pasien menunjukkan rasa tidak percaya dengan apa yang diucapkan oleh pendamping dan tidak mau mengalah dalam pembicaraan.

Awalnya sih banyak kesel. Karena bapak tuh kadang suka maunya begini, padahal seharusnya tidak begini. Kadang ngambil uang mau sekian juta. Padahal kan untuk apa? Jadi kita nggak pernah tau uangnya tuh untuk apa. Jadi suka gini, "Saya kehilangan uang”. Kalau lihat orang-orang sekitarnya itu kesannya nuduh, gitu. Aku tuh kasihan banget sama Pak Mail (asisten rumah tangga), Pak Mail tuh udah sampai begini, "Bu, saya kan nggak enak Bu dituduh terus, jadi saya keluar aja." Jadi kita biasanya agak kerasnya di situ, agak keras ke bapak nggak boleh nuduh seperti itu. Nggak boleh nuduh sembarangan. Pernah juga sih sekali bapak, apa ya, diskusi apa, tapi terusnya bapak tuh nggak percaya. Aku bilang sih ngeyel bapak tuh gitu. Sampai, "Ya udah kalau nggak percaya!”. Digebrak mejanya.

P3 menyatakan bahwa pasien terkadang berperilaku seperti anak kecil yang tidak bisa diberi tahu dan diatur. Contohnya ketika diberi tahu untuk segera tidur atau menghindari makanan tertentu. Pasien tetap saja tidak melakukan apa yang diminta oleh pendamping.

Kadang-kadang saya kesal, karena pertama mungkin kalau ibu saya seperti kalau anak kecil bandel lah gitu. Udah saya suruh ini, ya banyak melanggarnya. Banyak melanggar yang tidak boleh dimakan misalnya. Kalau kita larang tuh, ibu tuh marah.

Rasa malu adalah perasaan lain yang sering dirasakan oleh P1 selama merawat pasien. Rasa malu disebabkan oleh perilaku pasien yang dianggapnya merepotkan dan menyusahkan orang lain. P1 dan keluarganya aktif berkegiatan di komunitas gereja. Beberapa contoh perilaku pasien yang 
dianggap memalukan adalah ketika pasien menelepon pengurus gereja di pagi buta, memarahi sesama jemaat dan melarang mereka untuk tidak datang berkunjung ke rumah. P1 terus-menerus merasa malu sampai memiliki keinginan untuk menghindar dari orang lain karena tak sanggup menanggung malu.

Kadang-kadang saya ketemu orang-orang di gereja malu... Ada... Gitu. Aduh maaf... maaf sekali kan. Kan orang udah dateng ngelayanin ya, Kelakuan mami...Tadi udah nyusahin orang, gitu kan, maksudnya.

Di samping sering merasa kesal pada pasien, P2 pun merasa khawatir akan kondisi pasien yang sedang sakit dan kemampuan dirinya untuk berdaya ketika merawat pasien. Karakteristik khas penyakit demensia yang bersifat kronis membuat pendamping terus-menerus merasa khawatir akan kondisi pasien.

Saya rasakan ternyata mendampingi orang sakit itu lebih banyak khawatirnya banyak cemasnya banyak. Emosi-emosi negatif yang malah justru bikin, malah justru mungkin mempersulit emosi. Terus merasa khawatir saya tidak bisa berbuat apa-apa gitu.

Selain merasakan perasaa kesal, P3 juga sering merasa kasihan melihat kondisi pasien yang mengalami demensia karena ia membandingkan keadaan pasien dahulu dan sekarang. Perbedaan yang begitu besar membuatnya merasa berat melihat pasien menderita, dalam hal ini kondisi fisik dan psikis yang terus-menerus menurun.

Kadang-kadang juga banyak excuse juga ke ibu. Kasihan. Ibu saya jauh, jauuh dengan dulu. Kalau dulu, ibu saya modis banget kalau ke kampus, kalau ngajar itu. Iya, itu kasihannya. Kok gini amat gitu ya. Berarti mungkin karena kita salah penanganan atau memang karena kondisinya sudah begitu, saya nggak mengerti juga. Lebih banyak kasihan.

\section{DISKUSI}

Penelitian ini bertujuan untuk mengetahui gambaran kesejahteraan subjektif pada perempuan dewasa yang merawat orang tua dengan demensia yang dilihat melalui evaluasi kognitif dan afektif. Evaluasi kognitif merujuk pada penilaian kepuasan hidup yang didasarkan pada standar masing- 
masing individu (Diener dkk., 2002). Pada bagian evaluasi kognitif, terdapat dua tema yang muncul yaitu pengaturan tinggal bersama atau manajemen keluarga dan relasi sosial dengan pasien. Pendamping dalam penelitian ini mengalami ketidakpuasan dalam kehidupan mereka dan sebagian pendamping lainnya ditemukan puas dengan kondisi kehidupannya saat ini. Keempat pendamping merasa tidak sejahtera secara emosional karena perasaan yang berhubungan dengan aktivitas perawatan mayoritas negatif. Dua pendamping tidak puas dengan kondisi kehidupannya dan perasaan cenderung negatif, sedangkan dua pendamping lainnya secara kognitif merasa puas dengan hidupnya dan perasaan cenderung negatif.

Pengalaman pendamping orang tua dengan demensia dapat dipengaruhi oleh bagaimana keluarga mengatur kehidupannya ketika ada anggota keluarga lain yang sakit. Keluarga menjadi sumber utama perawatan bagi pasien lansia yang kehilangan kapasitas untuk hidup mandiri (World Health Organization, 2015). Mayoritas dukungan dan bantuan yang diberikan pada pasien demensia datang dari anggota keluarga (Schulz \& Martire, 2004). Pasien demensia pada umumnya membutuhkan lebih banyak dukungan dan bantuan dari pendamping dibandingkan dengan pasien penyakit lainnya (Pinquart \& Sorensen, 2003; Spector \& Kemper, 1994). Pengaturan tinggal bersama atau manajemen keluarga yang diterapkan dalam keluarga dengan pasien demensia juga dapat berperan terhadap beban yang dialami oleh pendamping (Cox \& Albisu, 2003).

Hubungan antara anggota keluarga pendamping dan pasien demensia tidak hanya sebatas relasi perawat dengan pasien saja, tetapi meliputi hubungan antara orang tua dan anak yang sudah terjalin lama. Rasa kehilangan akan sosok orang tua adalah salah satu pengalaman yang umum dialami oleh anggota keluarga pendamping pasien demensia (Kjällman-Alm dkk., 2013). Berdasarkan hasil penelitian Kjällman-Alm dkk. (2013), menjadi anak dewasa yang merawat orang tua dengan demensia berarti menjalani peran sebagai 'orang tua' bagi pasien. Studi tersebut juga menunjukkan bahwa pendamping berduka atas kehilangan sosok orang tua dan pada saat yang bersamaan memiliki harapan untuk bisa merasa dekat kembali dengan orang tua. Partisipan dalam penelitian tersebut menyatakan bahwa mereka merindukan sosok orang tua sebelum sakit yang bisa diminta nasihatnya, menjadi tempat bergantung dan mencari dukungan.

Relasi sosial pasien bisa dijelaskan juga dari keinginan pendamping untuk membantu pasien menjadi lebih semangat dan positif. Maka dari itu, pendamping melihat dirinya harus lebih siap secara fisik dan psikologis untuk merawat pasien. Seperti halnya kondisi pasien demensia mempengaruhi pendamping, kondisi pendamping juga dapat mempengaruhi pasien. Sebagai contohnya, satu studi 
sebelumnya menjelaskan bahwa ketika pendamping merasa marah dan frustrasi, pasien dengan demensia akan lebih cenderung menjadi sama kesalnya (Yuhas dkk., 2006).

Seberapa puas seseorang mengenai kehidupan yang dijalani bergantung pada perbandingan antara keadaan diri saat ini dengan apa yang dianggap sebagai standar yang sesuai (Diener dkk., 1985). Terdapat dua pendamping yang terkesan puas akan kehidupannya dan dua pendamping lainnya yang cenderung mengalami ketidakpuasan. Pendamping yang terkesan puas akan kondisi kehidupannya menyatakan bahwa gambaran kehidupan ideal dan gambaran kehidupan saat ini tidak berbeda. Perbedaan bisa muncul karena apa yang diharapkan pendamping tidak sesuai dengan kondisi kehidupan saat ini. Dengan kata lain, terdapat ketidaksesuaian antara ekspektasi mengenai kehidupan dan kenyataan yang dihadapi sebagai anggota keluarga pendamping pasien demensia. Kesesuaian antara ekspektasi dan kenyataan menjadi penting untuk menjelaskan kepuasan hidup karena pendamping melakukan evaluasi kehidupan menggunakan kriteria pribadi yang secara langsung diaplikasikan pada kehidupannya. Peristiwa kehidupan yang penuh tekanan memang dapat memberikan dampak negatif terhadap kepuasan hidup seseorang, akan tetapi pada akhirnya individu akan dapat menyesuaikan diri dengan tantangan-tantangan baru (Diener dkk., 2006).

Pada pendamping yang puas akan kondisi kehidupannya, gambaran kehidupan ideal dan kondisi kehidupan saat ini dapat sesuai karena penyesuaian yang dilakukan dan dukungan sosial yang diterima. Salah satu pendamping berusaha untuk menerima situasi baru dengan menyesuaikan diri di situasi baru. Pendamping lainnya mendapatkan dukungan sosial dari anggota keluarga, pasangan dan teman. Ketika dihadapkan pada situasi kehidupan yang sulit, orang-orang bisa menjaga kesejahteraan dirinya dengan mencari makna, mengembangkan dirinya dan menjalin relasi sosial (Ryff, 2014). Dukungan sosial yang diterima pendamping berhubungan dengan meningkatnya motivasi untuk melakukan peran pendamping (Grover dkk., 2017). Pada studi Van Wijngaarden dkk. (2018), pendamping yang mampu untuk menghadapi kesulitan yang tidak dapat dihindari dan ketidakpastian dari kondisi demensia "memilih" untuk berhenti melawan dan mencoba untuk hidup dengan demensia sembari menghadapi krisis eksistensial yang dialami.

Ketika melihat bagian evaluasi kognitif, ada kondisi yang belum bisa diterima oleh pendamping. Ketidakpuasan atas kondisi kehidupan pada beberapa pendamping muncul dari kesenjangan antara kondisi kehidupan saat ini dan gambaran kehidupan ideal. Pendamping yang melihat adanya kesenjangan ini berusaha untuk merubah dan menerima gambaran kehidupan baru. Namun, temuan penelitian menunjukkan bahwa masih terdapat keengganan dan perlawanan atas situasi yang dihadapi. Keterpaksaan untuk menerimaan dianggap sebagai satu-satunya cara yang bisa 
dilakukan untuk menangani kondisi kehidupan. Hal ini terlihat dari kutipan pernyataan pendamping, "mau bagaimana lagi" atau "saya harus menerima".

Penelitian pada pasien yang mengalami penyakit kronis menunjukkan bahwa proses penerimaan pasien terhadap kondisi kesehatannya tidak bersifat linier (Paterson, 2001). Pengalaman pasien penyakit kronis dilihat sebagai proses di mana pasien mengalami pergeseran perspektif untuk memahami pengalaman mereka. Proses penerimaan bisa "berubah" dalam konteks personal dan sosial yang seringkali ditunjukkan dengan ketidakmampuan untuk memperhatikan aspek kehidupan lainnya. Terdapat bagian dari diri manusia yang ketika dihadapkan pada suatu ancaman akan merespon secara defensif dengan menyangkal kenyataan atau berusaha berandai-andai (Mount \& Flanders, 2003). Di satu sisi pendamping memiliki harapan atas kondisi kehidupannya tetapi pada saat yang bersamaan mereka pun menyadari bahwa kondisi sakit di luar kendalinya.

Untuk menyelesaikan dilema dalam proses penerimaan kondisi kehidupan, pendamping mengharuskan dirinya sendiri untuk menerima situasi yang dihadapi saat ini. Temuan ini sejalan dengan hasil penelitian pada pasien diabetes di mana mereka memperlihatkan 'keharusan' untuk menerima kondisi sakit digunakan sebagai 'syarat' untuk menjalani kehidupan yang baik (Johansson, Ekebergh \& Dahlberg, 2009). Bagi pasien diabetes pada penelitian tersebut, menetapkan 'keharusan' adalah refleksi dari keterbatasan pilihan yang bisa diambil. Penerimaan yang diutarakan pendamping dalam penelitian ini terkesan 'palsu' dan dilakukan agar tetap dapat menjalani kehidupan. Pada penelitian Van Wijngaarden dkk. (2018) dijelaskan bahwa ketika pendamping mencoba menjalani kehidupan seperti biasa, mereka akan tetap merasa terombang-ambing antara 'menolak' apa yang terjadi dan menerima kesulitan yang dihadapi.

Bagaimana pendamping menilai dan menangani kondisi kehidupannya mungkin dipengaruhi oleh budaya. Dalam relasi antara orang tua dan anak di Indonesia, anak harus menunjukan rasa hormat kepada orang tua, mematuhi orang tua, dan menjaga kehormatan keluarga (Abubakar dkk., 2015; Riany dkk., 2017; Yee, 1997). Selain itu, sudah menjadi hal yang umum di Indonesia ketika orang tua pensiun dan memasuki usia lansia, anak-anak diharapkan untuk mengurus dan merawat orang tuanya (Beard \& Kunharibowo, 2001; Keasberry, 2001; Riany dkk., 2017). Dalam konteks merawat pasien demensia, anggota keluarga yang menjadi pendamping terutama anak seringkali merasa terdorong untuk bertanggung jawab merawat orang tua yang lansia sebagai bentuk kewajiban anak terhadap orang tua (Guo dkk., 2019; Piiparinen \& Whitlatch, 2011). Merawat orang tua dengan demensia juga dipandang sebagai cara untuk "membayar" jasa dan usaha orang tua (Albinsson \& Strang, 2003). Pengambilan data yang rentan akan social desirability membuat pendamping 
menjawab sesuai dengan bagaimana "selayaknya" hubungan orang tua dan anak, sehingga mereka memberikan jawaban yang normatif.

Evaluasi afektif dilakukan dengan melihat perasaan yang dialami seseorang meliputi frekuensi dari pengalaman tersebut (Diener dkk., 2002). Dalam konsep kesejahteraan subjektif, seseorang dinilai sejahtera secara emosional jika dirinya lebih sering merasakan afek positif dan jarang mengalami afek negatif (Diener, 1994). Pengalaman pendamping yang berkaitan dengan aktivitas perawatan diwarnai oleh afek negatif seperti perasaan kesal, malu, khawatir, dan kasihan. Perasaan negatif tersebut dapat muncul akibat kejadian spesifik yang dialami selama melakukan perawatan seperti ketika sedang berkomunikasi dengan pasien atau meminta pasien melakukan sesuatu. Pada pendamping pasien demensia, sumber stres utama adalah masalah perilaku pasien, seperti emosi yang meledak-ledak dan perilaku yang tidak pantas (Pinquart \& Sörensen, 2004; Pinquart \& Sörensen, 2007). Karakteristik pasien demensia yang sulit untuk diajak berkomunikasi, tidak mau mengalah, dan bertingkah laku seperti anak kecil menimbulkan stres tersendiri bagi pendamping. Walaupun begitu, pendamping tetap bisa merasakan perasaan positif yang berasal dari pengalaman positif selama merawat pasien, seperti merasa senang karena bisa membantu anggota keluarga (Marks dkk., 2002).

Penjelasan alternatif mengapa perasaan negatif terkait aktivitas perawatan mewarnai dunia afek pendamping berkaitan dengan evaluasi kognitif mereka atas kondisi kehidupannya. Hidup dengan orang tua yang menderita demensia digambarkan oleh ancaman terhadap kenyataaan dan eksistensi seseorang (Kjällman-Alm dkk., 2013). Pendamping berada pada situasi yang mengancam eksistensi fisik, identitas sosial dan kemampuannya untuk merasa puas dalam hidup. Anak dari pasien demensia dibebani dengan tanggung jawab untuk merawat walaupun merasakan kesedihan dan kehilangan yang mendalam. Rasa kehilangan meliputi melihat orang tua berubah menjadi orang asing yang berperilaku tidak tidak layak dan menyadari bahwa orang tua yang mereka kenal menghilang secara perlahan (Høgsnes dkk., 2016).

Terdapat beberapa limitasi dalam penelitian ini. Pertama, jumlah sampel yang sangat kecil, bahkan untuk studi kualitatif. Sedikitnya jumlah partisipan mempersulit proses penentuan tema karena jawaban partisipan terlalu bervariasi. Peneliti hanya merekrut sampel kecil serta terdapat partisipan yang mengundurkan diri dari penelitian. Lalu, perekrutan partisipan penelitian menggunakan survei daring juga mungkin tidak tersebar secara luas kepada individu-individu yang berpotensi menjadi calon partisipan. Kedua, peneliti tidak mempertimbangan status sosial dan ekonomi dari partisipan yang mungkin berpengaruh terhadap kesejahteraan subjektifnya. Namun 
mempertimbangkan status pendidikan seluruh partisipan yang menamatkan perguruan tinggi, dapat diasumsikan bahwa status sosial dan ekonomi partisipan cukup homogen meski tidak ditanyakan secara langsung. Selain itu, terdapat satu pendamping yang memiliki durasi merawat pasien paling lama dibandingkan pendamping yang lain, yang mungkin bisa memengaruhi dinamika pengalaman pendamping.

\section{SIMPULAN DAN SARAN}

\section{Simpulan}

Secara umum, kesejahteraan subjektif perempuan dewasa yang merawat orang tua dengan demensia menunjukkan variasi yang berbeda pada masing-masing komponen. Pada evaluasi kognitif, beberapa pendamping dalam penelitian ini mengalami ketidakpuasan dalam kehidupan mereka dan sebagian pendamping lainnya ditemukan puas dengan kondisi kehidupannya saat ini. Pada evaluasi afektif, keempat pendamping merasa tidak sejahtera secara emosional karena perasaan-perasaan yang berhubungan dengan aktivitas perawatan mayoritas negatif.

\section{Saran Teoretis}

Penelitian dalam tema ini sebaiknya melibatkan partisipan lebih banyak agar hasil penelitian agar dapat memudahkan proses penentuan tema. Penjaringan partisipan dapat dilakukan di tempat lain seperti rumah sakit, puskesmas, komunitas penderita demensia atau panti wreda. Penelitian ini memiliki keterbatasan dalam variasi partisipan, di mana keempat partisipan dalam penelitian ini adalah anak dewasa perempuan. Oleh karena itu, penelitian selanjutnya dapat melibatkan partisipan dengan karakteristik (gender, usia, tingkat pendidikan, status pernikahan dan status hubungan) yang lebih bervariasi, guna mendapat gambaran yang lebih luas terkait pengalaman dan kondisi kesejahteraan subjektif anggota keluarga pendamping pasien demensia selain anak perempuan.

\section{Saran Praktis}

Hasil penelitian ini menunjukkan bahwa pengalaman merawat pasien demensia seringkali diwarnai perasaan negatif. Temuan ini dapat menjadi titik awal untuk memberikan layanan yang sesuai dengan kebutuhan pendamping. Pelayanan kesehatan sebaiknya tidak hanya fokus untuk memberikan pengetahuan, mengasah keterampilan pendamping dalam merawat tetapi juga membantu pendamping menangani berbagai perasaan negatif yang muncul selama melakukan 
perawatan dengan berempati dan memberikan dukungan emosional (Chai \& Kiat, 2019). Berdasarkan hasil penelitian, dapat dirancang program edukasi atau intervensi yang bertujuan untuk mempromosikan kesejahteraan subjektif beserta strategi-strategi yang bisa diaplikasikan untuk mengurangi beban pendamping selama merawat pasien demensia.

\section{UCAPAN TERIMA KASIH}

Peneliti mengucapkan terima kasih kepada Dr. Retno Hanggarani Ninin, S.Psi, M.Psi yang telah membantu dalam proses penulisan artikel.

\section{REFERENSI}

Abubakar, A., Van de Vijver, F. J., Suryani, A. O., Handayani, P., \& Pandia, W. S. (2015). Perceptions of parenting styles and their associations with mental health and life satisfaction among urban Indonesian adolescents. Journal of Child and Family Studies, 24(9), 2680 -2692. https://doi.org/ 10.1007/s10826-014-0070-x

Albinsson, L., \& Strang, P. (2003). Existential concerns of families of late-stage dementia patients: Questions of freedom, choices, isolation, death, and meaning. Journal of Palliative Medicine, 6(2), 225 -235. https://doi.org/ 10.1089/109662103764978470.

Alzheimer's Association. (2018). 2018 Alzheimer's disease facts and figures. https://alz.org/media/HomeOffice/Facts\%20and\%20Figures/facts-and-figures.pdf

Badan Pusat Statistik. (2019). Statistik penduduk lanjut usia 2019. https://www.bps.go.id/publication/2019/12/20/ab17e75dbe630e05110ae53b/statistikpenduduk-lanjut-usia-2019.html

Bailes, C. O., Kelley, C. M., \& Parker, N. M. (2016). Caregiver burden and perceived health competence when caring for family members diagnosed with Alzheimer's disease and related dementia. Journal of the American Association of Nurse Practitioners, 28(10), 534 -540. https://doi.org/10.1002/2327-6924.12355

Beard, V. A., \& Kunharibowo, Y. (2001). Living arrangements and support relationships among elderly Indonesians: Case studies from Java and Sumatra. International Journal of Population Geography, 7(1), 17 -33. https://doi.org/10.1002/ijpg.202 
Bengtsson, M. (2016). How to plan and perform a qualitative study using content analysis. NursingPlus Open, 2, 8-14. https://doi.org/10.1016/j.npls.2016.01.001

Brodaty, H., \& Green, A. (2002). Defining the role of the caregiver in Alzheimer's disease treatment. Drugs \& Aging, 19(12), 891-898. https://doi.org/10.2165/00002512-200219120-00001

Chai, D. S. C., \& Kiat, P. Y. L. (2019). The role of general practitioners in helping caregivers of persons with dementia. The Singapore Family Physician, 45(5), 28-33. https://doi.org/10.33591/sfp.45.5.u6

Chaudhuri, J. D., \& Das, S. (2006). The role of caregivers in the management of alzheimer's disease: Examples from Asian Countries. Sultan Qaboos University Medical Journal, 6(2), 11-18. https://pubmed.ncbi.nlm.nih.gov/21748130/

Christensen, L.B. (2010). Experimental methodology (10th ed.). Pearson.

Cox, C. B., \& Albisu, K. (2003). The impact of caregiving for a relative with Alzheimer's disease: A comparison of those caring for persons living alone, spousal caregivers, and co-resident adult children. Journal of Mental Health And Aging, 9(1), 23-33.

Creswell, J. W. (2009). Research design: Qualitative, quantitative, and mixed methods approaches (4th ed). Sage.

Diener, E. (1994). Assessing subjective well-being: Progress and opportunities. Social Indicators Research, 31(2), 103-157. https://doi.org/10.1007/BF01207052

Diener, E. D., Emmons, R. A., Larsen, R. J., \& Griffin, S. (1985). The satisfaction with life scale. Journal of Personality Assessment, $49(1), \quad 71-75$. https://doi.org/10.1207/s15327752jpa4901_13

Diener, E., Lucas, R.E., \& Oishi, S. (2002). Subjective well-being: The science of happiness and life satisfaction. Dalam C. R. Synder \& S. J. Lopez (Eds.), Handbook of positive psychology (hlm. 187-194). Oxford University Press.

Diener, E., Lucas, R. E., \& Oishi, S. (2018). Advances and open questions in the science of subjective well-being. Collabra Psychology, 4(1), 1-78. https://doi.org/10.1525/collabra.115

Diener, E., Lucas, R. E., \& Scollon, C. N. (2006). Beyond the hedonic treadmill: Revising the adaptation theory of well-being. American Psychologist, 61(4), 305314. https://doi.org/10.1037/0003-066X.61.4.305

Diener, E., \& Ryan, K. (2009). Subjective well-being: A general overview. South African Journal of Psychology, 39(4), 391-406. https://doi.org/10.1177/008124630903900402 
Diener, E., Sapyta, J. J., \& Suh, E. (1998). Subjective well-being is essential to wellbeing. Psychological Inquiry, 9(1), 33-37. https://doi.org/10.1207/s15327965pli0901_3

Eid, M., \& Diener, E. (2004). Global judgments of subjective well-being: Situational variability and long-term stability. Social Indicators Research, 65(3), 245-277. https://doi.org/10.1023/B:SOCI.0000003801.89195.bc

Fianco, A., Sartori, R. D., Negri, L., Lorini, S., Valle, G., \& Fave, A, D. (2015). The relationship between burden and well-being among caregivers of Italian people diagnosed with severe neuromotor and cognitive disorders. Research in Developmental Disabilities, 39, 43-54. https://doi.org/10.1016/j.ridd.2015.01.006

Glasdam, S., Timm, H., \& Vittrup, R. (2010). Support efforts for caregivers of chronically ill persons. Clinical Nursing Research, 19(3), 233-265. https://doi.org/10.1177/1054773810369683

Goldberg, A., \& Rickler, K. S. (2011). The role of family caregivers for people with chronic illness. Rhode Island Medical Journal, 94(2), 41-42.

Graham, J., Spiliopoulou, P., Arbuckle, R., Bridge, J. A., \& Cassidy, J. (2017). A pilot study of subjective well-being in colorectal cancer patients and their caregivers. Patient Related Outcome Measures, 8, 111-119. https://doi.org/10.2147/PROM.S141815

Grover, S., Nehra, R., Malhotra, R., \& Kate, N. (2017). Positive aspects of caregiving experience among caregivers of patients with dementia. East Asian Archives of Psychiatry, 27(2), 71-78.

Guo, M., Kim, S., \& Dong, X. (2019). Sense of filial obligation and caregiving burdens among Chinese immigrants in the United States. Journal of the American Geriatrics Society, 67(S3), S564-S570. https://doi.org/10.1111/jgs.15735

Hajek, A., \& König, H. H. (2016). Informal caregiving and subjective well-being: Evidence of a population-based longitudinal study of older adults in Germany. Journal of The American Medical Directors Association, 17(4), 300-305. https://doi.org/10.1016/j.jamda.2015.10.015

Hamama, L., \& Sharon, M. (2013). Posttraumatic growth and subjective well-being among caregivers of chronic patients: A preliminary study. Journal of Happiness Studies, 14(6), 1717-1737. https://doi.org/10.1007/s10902-012-9405-8

Hammond, T., Weinberg, M. K., \& Cummins, R. A. (2014). The dyadic interaction of relationships and disability type on informal carer subjective well-being. Quality of Life Research, 23(5), 1535-1542. https://doi.org/10.1007/s11136-013-0577-4 
Hashimoto, A., Matsuoka, K., Yasuno, F., Takahashi, M., Iida, J., Jikumaru, K., \& Kishimoto, T. (2017). Frontal lobe function in elderly patients with Alzheimer's disease and caregiver burden. Psychogeriatrics, 17(4), 267-272. https://doi.org/10.1111/psyg.12231

Himawan, K. K. (2020). The single's struggle: Discovering involuntary singleness in indonesia through gender and religious perspectives. The Family Journal: Counseling and Therapy for Couples and Families, 28(4), 379-389. https://doi.org/10.1177/1066480720950419

Høgsnes, L., Norbergh, K. G., Danielson, E., \& Melin-Johansson, C. (2016). The shift in existential life situations of adult children to parents with dementia relocated to nursing homes. The Open Nursing Journal, 10, 122-130. https://doi.org/ 10.2174/1874434601610010122

Johansson, K., Ekebergh, M., \& Dahlberg, K. (2009). A lifeworld phenomenological study of the experience of falling ill with diabetes. International Journal of Nursing Studies, 46(2), 197203. https://doi.org/10.1016/j.ijnurstu.2008.09.001

Keasberry, I. N. (2001). Elder care and intergenerational relationships in rural Yogyakarta, Indonesia. Ageing \& Society, 21(5), 641-665.

Kjällman-Alm, A., Norbergh, K. G., \& Hellzen, O. (2013). What it means to be an adult child of a person with dementia. International Journal of Qualitative Studies On Health And Wellbeing, 8(1), 21676. https://doi.org/10.3402/qhw.v8i0.21676

Kristanti, M. S., Engels, Y., Effendy, C., Utarini, A., \& Vernooij-Dassen, M. (2018). Comparison of the lived experiences of family caregivers of patients with dementia and of patients with cancer in Indonesia. International Psychogeriatrics, 30(6), 903-914. https://doi.org/10.1017/S1041610217001508

Lloyd, J., Patterson, T., \& Muers, J. (2016). The positive aspects of caregiving in dementia: A critical review of the qualitative literature. Dementia, 15(6), 1534-1561. https://doi.org/10.1177/1471301214564792

Lucas, R. E., \& Baird, B. M. (2006). Global self-assessment. Dalam M. Eid \& E. Diener (Eds.), Handbook of multi-method measurement in Psychology (hlm. 29-42). American Psychological Association.

Maddux, J. E. (2018). Subjective well-being and life satisfaction: An introduction to conceptions, theories, and measures. Taylor \& Francis.

Marks, N. F., Lambert, J. D., \& Choi, H. (2002). Transitions to caregiving, gender, and psychological well-being: A prospective US national study. Journal of Marriage And Family, 64(3), 657-667. https://doi.org/10.1111/j.1741-3737.2002.00657.x 
Mount, B. M., \& Flanders, E. M. (2003). Existential suffering and the determinants of healing. European Journal of Palliative Care, 10(2), 40-42.

Paterson, B. L. (2001). The shifting perspectives model of chronic illness. Journal of Nursing Scholarship, 33(1), 21-26. https://doi.org/10.1111/j.1547-5069.2001.00021.x

Patterson, C. (2018). World alzheimer report 2018: The state of the art of dementia research: New frontiers. Alzheimer's Disease International

(ADI). https://www.alz.co.uk/research/WorldAlzheimerReport2018.pdf

Peña-Longobardo, L. M., \& Oliva-Moreno, J. (2015). Caregiver burden in Alzheimer's disease patients in Spain. Journal of Alzheimer's Disease, 43(4), 1293-1302. https://doi.org/10.3233/JAD-141374.

Perren, S., Schmid, R., \& Wettstein, A. (2006). Caregivers' adaptation to change: The impact of increasing impairment of persons suffering from dementia on their caregivers' subjective wellbeing. Aging and Mental Health, 10(5), 539-548.

Piiparinen, R., \& Whitlatch, C. J. (2011). Existential loss as a determinant to well-being in the dementia caregiving dyad: A conceptual model. Dementia, 10(2), 185-201. https://doi.org/10.1177/1471301211398989

Pinquart, M., \& Sörensen, S. (2003). Differences between caregivers and noncaregivers in psychological health and physical health: A meta-analysis. Psychology and Aging, 18(2), 250267. https://doi.org/10.1037/0882-7974.18.2.250

Pinquart, M., \& Sörensen, S. (2004). Associations of caregiver stressors and uplifts with subjective well-being and depressive mood: A meta-analytic comparison. Aging \& Mental Health, 8(5), 438-449. https://doi.org/10.1080/13607860410001725036

Pinquart, M., \& Sörensen, S. (2007). Correlates of physical health of informal caregivers: A metaanalysis. The Journals of Gerontology Series B: Psychological Sciences and Social Sciences, 62(2), 126-137. https://doi.org/10.1093/geronb/62.2.P126

Queirós, A., Faria, D., \& Almeida, F. (2017). Strengths and limitations of qualitative and quantitative research methods. European Journal of Education Studies, 3(9), 369-387. https://doi.org/10.5281/zenodo.887089

Riany, Y. E., Meredith, P., \& Cuskelly, M. (2017). Understanding the influence of traditional cultural values on Indonesian parenting. Marriage \& Family Review, 53(3), 207-226. 
Ryff, C. D. (2014). Self-realisation and meaning making in the face of adversity: A eudaimonic approach to human resilience. Journal of Psychology in Africa, 24(1), 1-12. https://doi.org/10.1080/14330237.2014.904098

Schwarz, N., \& Strack, F. (1999). Reports of subjective well-being: Judgmental processes and their methodological implications. Dalam D. Kahneman, E. Diener, \& N. Schwarz (Eds.), Wellbeing: The foundations of hedonic psychology (hlm. 61-84). Russell Sage.

Schulz, R., \& Martire, L. M. (2004). Family caregiving of persons with dementia: prevalence, health effects, and support strategies. The American Journal of Geriatric Psychiatry, 12(3), 240-249. https://doi.org/10.1097/00019442-200405000-00002

Shakeel, S., Rana, S. A., \& Malik, N. I. (2015). Burden of care, mental health and subjective well being of family caregivers of elderly patients. Pakistan Journal of Professional Psychologists, 6(1), 1-16.

Singh, G., \& Dubey, A. (2016). Mental health and well-being of caregivers: A review of the literature. The International Journal of Indian Psychology, 3(4), 98-105.

Spector, W. D., \& Kemper, P. (1994). Disability and cognitive impairment criteria: targeting those who need the most home care. The Gerontologist, 34(5), 640-651. https://doi.org/10.1093/geront/34.5.640

Sullivan, A. B., \& Miller, D. (2015). Who is taking care of the caregiver? Journal of Patient Experience, 2(1), 7-12. https://doi.org/10.1177/237437431500200103

Tremont, G. (2011). Family caregiving in dementia. Medicine and Health, 94(2), 36-38.

Tumanggor, R. D. (2020). Female caregiver devotion as a stress factor in caring for hospitalized elderly in Indonesia. International Journal of Nursing Education, 12(2), 106-111.

Van den Berg, B., Fiebig, D. G., \& Hall, J. (2014). Well-being losses due to care-giving. Journal of Health Economics, 35, 123-131.https://doi.org/10.1016/j.jhealeco.2014.01.008

Van Wijngaarden, E., Van der Wedden, H., Henning, Z., Komen, R., \& The, A.M. (2018). Entangled in uncertainty: The experience of living with dementia from the perspective of family caregivers. PloS One, 13(6), 1-21. https://doi.org/10.1371/journal.pone.0198034

Vizzachi, B. A., Daspett, C., Cruz, M. G. D. S., \& Horta, A. L. D. M. (2015). Family dynamics in face of Alzheimer's in one of its members. Revista da Escola de Enfermagem da USP, 49(6), 931-936. http://dx.doi.org/10.1590/S0080-623420150000600008 
Wilson, R. S., Segawa, E., Boyle, P. A., Anagnos, S. E., Hizel, L. P., \& Bennett, D. A. (2012). The natural history of cognitive decline in Alzheimer's disease. Psychology and Aging, 27(4), 1008. http://dx.doi.org/10.1037/a0029857

World Health Organization. (2006). Neurological disorders: Public health challenges. https://www.who.int/mental_health/publications/neurological_disorders_ph_challenges/en/

World Health Organization. (2015). Supporting informal caregivers of people living with dementia. https://www.who.int/mental_health/neurology/dementia/dementia_thematicbrief_informal_ca re.pdf

World Health Organization. (2019). Dementia fact sheets. https://www.who.int/news-room/factsheets/detail/dementia

Yee, B. W. K. (1997). The social and cultural context of adaptive aging by Southeast Asian elders. Dalam J. Sokolovsky (Ed.), The cultural context of aging: Worldwide perspectives (hlm. 293303). Praeger.

Yu, D. S. F., Cheng, S. T., \& Wang, J. (2018). Unravelling positive aspects of caregiving in dementia: An integrative review of research literature. International Journal of Nursing Studies, 79, 126. https://doi.org/10.1016/j.ijnurstu.2017.10.008

Yuhas, N., McGowan, B., Fontaine, T., Czech, J., \& Gambrell-Jones, J. (2006). Psychosocial interventions for disruptive symptoms of dementia. Journal of Psychosocial Nursing and Mental Health Services, 44(11), 34-42. https://doi.org/10.3928/02793695-20061101-06 